\title{
Esélyegyenlőség-vizsgálat utánpótláskorú labdarúgók körében
}

\section{Equity examination among youth soccer players}

\section{Tóth Péter László1, Dóczi Tamás²}

1 Emberi Erőforrások Minisztériuma, Sportért Felelős Államtitkárság, Nemzeti Utánpótlás-nevelési Főosztály, Budapest

2 Testnevelési Egyetem, Gazdaság és Társadalomtudományi Intézet, Társadalomtudományi Tanszék, Budapest

\begin{abstract}
Absztrakt - A tanulmány az utánpótlássportban megnyilvánuló társadalmi esélyegyenlőtlenség témakörét járja körül. Célja a labdarúgás példáján keresztül azonosítani, hogy pontosan milyen dimenziók mentén értelmezhetőek azok az esélykülönbségek, amelyek akár szelekciós tényezőkké is válhatnak a gyermekek versenysportba történó bekapcsolódása során. Az összefüggések minél mélyrehatóbb feltárása érdekében kvalitatív és kvantitatív módszereket egyaránt alkalmaztunk. Elemzésünk fókuszában a labdarúgó akadémiai képzésben részt vevő fiatalok társadalmi környezetének vizsgálata állt. A kiemelt utánpótlásképző központként múködő Sándor Károly Labdarúgó Akadémián tett látogatása alkalmával a tanulmány első szerzője mélyinterjút készített az intézmény szakmai igazgatójával, illetve survey módszer segítségével kvantitatív és kvalitatív adatgyújtést végezett. Kérdőíves felmérésünk alanyai ( $\mathrm{N}=42)$ három akadémiai korosztály (U16-os, U17-es és U19-es korosztály) sportolói közül kerültek ki. Kutatási eredményeink rámutatnak, hogy a labdarúgás utánpótlás-nevelésének rendszere sem mentes a társadalmi esélyegyenlótlenségtól. A survey vizsgálattal nyert adatok alapján elmondható, hogy a kiemelt utánpótlásképző központokba túlnyomórészt jó anyagi és életkörülményekkel jellemezhetó családokból érkeznek a fiatalok. A területi dimenzió mentén végrehajtott elemzés rávilágított, hogy a származási település ugyancsak meghatározó. A gazdasági tekintetben elmaradottabb térségekból sokkal nehezebb bekerülni az elitképzést nyújtó intézményekbe, mint a fejlettebb régiókból. A sportbeli esélyegyenlótlenség ezen strukturális okainak feltárása mellett a kutatás legfóbb eredménye a sportban értelmezhető kulturális és társadalmi tőke jelentőségének azonosítása. Azok a gyermekek, akiknek családjában található sportmúlttal rendelkező személy, nagyobb eséllyel kapcsolódnak be a versenysportba. Az esélykülönbségek színtereinek bemutatását és magyarázó elemzését követóen, a következtetések levonása után javaslatokat fogalmazunk meg az egyenlőtlenségek enyhítésére.
\end{abstract}

Kulcsszavak: utánpótlássport, labdarúgó akadémiák, hátrányos helyzetú fiatalok, esélyegyenlótlenségi dimenziók, sportkarrier

\begin{abstract}
This paper focuses on the topic of social inequality manifested in youth sports. Its aim is to identify, through the example of football, what exactly are those dimensions along which inequalities in the opportunities that could even become factors of selecting children into competitive sports can be interpreted. In order to explore the relationships from more aspects, both qualitative and quantitative methods were applied. The analysis focuses on the social environment of young talents trained and educated in football academies. During the first author's visit at Sándor Károly Football Academy, operating as a special centre for the education of young talents, an in-depth interview with the professional director of the institution was conducted and quantitative and qualitative data were also collected using the survey method. The subjects of the survey by questionnaire $(\mathrm{N}=42)$ were selected from athletes of three academic age groups (the U16, U17 and U19 classes). The results of the research demonstrate that the system of educating young talents in football can also be characterised by unequal opportunities. Based on
\end{abstract}


the data obtained by the analysis, it can be said that most of the young athletes come from families with high social status and a good standard of living. The analysis has revealed that the location of origin also plays a determining role. It is much more difficult to get into institutions providing the highest level of sport education from economically disadvantaged regions than from more developed ones. The structural causes of inequality in sports, the most important result of this research, is the identification of the significance of cultural and social capital, as can be interpreted in sports. Those children who have a person with a history in sports in the family stand a better chance to get involved in competitive sports. After the presentation and explanatory analysis of unequal opportunities, the drawing of conclusions and the proposals are put forward for alleviating the inequalities.

Keywords: youth sports, football academies, socially disadvantaged youth, dimensions of social inequality, sports career

\section{Bevezetés}

Noha a közvélekedés szerint kevés olyan társadalmi alrendszer van, ahol az esélyegyenlöség oly mértékben megvalósul, mint a sport területén, az elmúlt évtizedek tudományos kutatási eredményei ennek az ellenkezőjét bizonyítiák (Földesiné, Gál és Dóczi, 2010; Coakley, 2015). Jelen tanulmány elsődleges célja egyrészt az elméleti (jogszabályi, szakirodalmi) háttér feltárása, másrészt az utánpótláskorú labdarúgók körében végzett empirikus vizsgálat eredményének bemutatása. Mivel a nemzetközi és a hazai szakirodalomban is meglehetősen szűk a labdarúgás utánpótlás-nevelését társadalomtudományi aspektusból vizsgáló munkák köre, a sportágban tapasztalható jelenségek hátterének tanulmányozására empirikus, esettanulmány-jellegü kutatást végeztünk. Főbb kutatási kérdések: Miként jelentkezik gyermekkorban a sporttal kapcsolatos esélyegyenlöség/esélyegyenlőtlenség? Vajon igaz-e az a feltételezés, amely szerint a kedvezőtlen társadalmi helyzetben lévő fiatalok lehetőséget sem kapnak talentumuk kibontakoztatására? Valóban bekövetkezhet, hogy „már a startnál elvesznek a tehetségek?"(Velenczei, Kovács, Szabó és Szabó, 2008).

Az 1997. évi XXXI. törvény a gyermekek védelméről és a gyámügyi igazgatásról kimondja, hogy „a hátrányos helyzetü és a halmozottan hátrányos helyzetü gyermeknek joga van ahhoz, hogy fokozott segitséget kapjon a fejlödését hátráltató körülmények leküzdéséhez és esélyeinek növeléséhez."

A hatályos jogszabály idézett tartalmi eleme alapján arra a következtetésre juthatnánk, hogy az esélyegyenlőség mindenki számára biztosított - ha máshogyan nem is, az állami szerepvállalásnak köszönhetően mindenképpen. A szociológiai témájú kutatások eredményei azonban arra mutatnak rá, hogy a különböző társadalmi és gazdasági státuszú szülők gyermekeinek esélyei korántsem azonosak. Ez alól a sport színtere sem kivétel. Bár az utánpótláskorú fiatalok között tapasztalható esélykülönbségek feltárása sokáig elkerülte a kutatók érdeklődését, az utóbbi években születtek hiánypótló munkák ebben a témakörben (Egressy, 2005; Velenczei, 2012).

A sportban való részvétellel kapcsolatos esélyegyenlőség vizsgálatakor eligazodást nyújtanak a társadalmi rétegződésről szóló elméleti alapok. Az utánpótlás-nevelés területén támpontként alkalmazható Pierre Bourdieu francia társadalomtudós modellje a tőketípusokról (Bourdieu, 2000). A három beazonosított tőkefajta - gazdasági, kulturális és szociális tőke - mindegyike meghatározó jelentőséggel bírhat a fiatalok versenysportolóvá válásának folyamatában. Természetesen esetükben még nem a saját, hanem a szüleik társadalmi és gazdasági státusza a mérvadó. Emellett az sem elhanyagolható szempont, hogy a családtagok mekkora kulturális tőkével rendelkeznek a sportot illetően. Ha a gyermek azt látja, hogy szülei életében a testmozgás szerves részét képezi a mindennapoknak, nyomon követik a sporteseményeket, tisztában vannak a különböző sportágak szabályaival, akkor jó eséllyel pozitív attitủd alakul ki benne a sport iránt. Ennek oka, hogy - bár az iskola és a kortárs csoportok befolyása is jelentős - az elsődleges szocializációs közeg a család (Földesiné, Gál és Dóczi, 2010; Coakley, 2015).

${ }^{1}$ Forrás: 1997. évi XXXI. törvény a gyermekek védelméröl és a gyámügyi igazgatásról. II. Fejezet, 6. S (2a) 
A négyévente lefolytatott nagymintás iffúságkutatás eredményei is alkalmasak lehetnek az elemzésre, mert a vizsgált (15-29 éves) korosztály magában foglalja az utánpótláskorú sportolók egy csoportját. A Magyar Ifjúság 2012 tanulmánykötetben arról olvashatunk, hogy a nemzetközi tendenciákhoz (Boraccino et al., 2009; Stalsberg és Pedersen, 2010) hasonlóan Magyarországon is empirikusan igazolhatóak a társadalmi egyenlőtlenségek sportolási részvételre gyakorolt hatásai (Dóczi, 2014; Gál, 2008; Fábri, 2002; Nyerges és Laki, 2004; Perényi, 2010). Ugyanakkor arról sem feledkezhetünk meg, hogy 2011-ben a társasági adóról és az osztalékadóról szóló 1996. évi LXXXI. törvény (TAO tv.) módosításával egy olyan horderejü sportpolitikai döntés született, amelynek következtében bizonyos sportágak utánpótlás-nevelésének finanszírozása rendkívül jelentős forrással bővült. Ennek okán joggal merül fel a kérdés, hogy a sportegyesületek és sportvállalkozások megnövekedett bevételei mennyiben mérsékelték a szülők anyagi ráfordításait - ezáltal hozzájárulva gyermekek esélyegyenlőségének megteremtéséhez.

A kérdés megválaszolásához elengedhetetlen az utánpótlássportban tapasztalható jelenségek objektív szemügyre vétele. Jelen kutatás vizsgálati terepét a magyar labdarúgás egyik kiemelt utánpótlás-nevelő intézménye, a Sándor Károly Labdarúgó Akadémia képezte. A tanulmány elsősorban a fiatalok társadalmi hátterére fókuszál, azon belül kiemelten az esélyegyenlőség/esélyegyenlőtlenség megjelenésére életükben. Választ keres arra a kérdésre, hogy a hátrányos helyzetű, de tehetséges gyermekek számára vezethet-e út a jövő élsportolóit képző „műhelyekbe". Mindemellett cél annak feltárása is, hogy a labdarúgó akadémiák milyen szerepet tölthetnek be abban, hogy a sport a társadalmi mobilitás eszközévé váljon.

\section{Elméleti háttér}

\section{Esélyegyenlöség - egyenlötlenség - hátrányos helyzet}

Azún.esélyegyenlőségi(vagyantidiszkriminációs) jog születése a második világháborút követő évekre tehető. A jogszabályok legfőbb célja a hátrányos megkülönböztetéssel szembeni védelem biztosítása volt (Balogh, Kádár, Majtényi és Pap, 2010). Alapdokumentumnak tekintheto „Az emberi jogok egyetemes nyilatkozata / Universal Declaration of Human Rights" (1948), amely összefoglalja az Egyesült Nemzetek Szervezetének álláspontját a minden embert megillető jogokról. Szintén irányadó dokumentumként tartjuk számon „Az Európai Unió alapjogi chartájá-t / Charter of Fundamental Rights of the European Union” (2000), amely „Az emberi jogok egyetemes nyilatkozatá"-hoz hasonló állásfoglalást tartalmaz. Az utóbbi évtizedek szociálpolitikai dokumentumai tükrözik azt a szemléletet, (ami egyfajta elmozdulásra utal az egyenlőség eszményétől), amely a vagyon újraelosztásán keresztül érhető el, az esélyegyenlőség eszménye felé, amely a lehetőségek újraelosztását célozza (Kelly, 2011).

A magyarországi esélyegyenlöségi politika jelentős lemaradással követte a külföldi tendenciákat, csak az 1990-es évek végére ismerték fel, hogy az esélyegyenlőség kérdéskörével időszerű foglalkozni (Bodnár, 2015). Az addig széttagolt intézkedések után mérföldkőnek számított a 2003. évi CXXV. törvény az egyenlő bánásmódról és az esélyegyenlőség előmozdításáról, ami az önkormányzatokat esélyegyenlöségi terv készítésére kötelezte. Ezek a dokumentumok azonban többnyire csak az esélyegyenlőség biztosításának stratégiáját tartalmazzák, és nem tesznek említést a szociális felzárkóztatás megvalósítását célzó konkrét projektekről. Érdekes megfigyelni például, hogy - bár közösségfejlesztő és társadalmi integrációt segítő funkciója ma már közismert - még a sikeres vidéki sportvárosok esélyegyenlőségi terveiben sem szerepel a sport (Balogh et al., 2010).

A sportot körülvevő jogi környezet biztosítja az esélyegyenlőség megteremtését célzó intézkedések törvényi kereteit. Ugyanakkor felvetődik a kérdés, hogy a jogszabályi előírások mennyiben valósulnak meg a gyakorlatban. A sporttörvényben rögzített állami szerepvállalás eredményessége például sok esetben nemcsak az állam teljesítőképességén múlik, hanem az önkormányzatok tehetősségén is (Bodnár, 2015). A jogszabályi előírások lehetővé tették, hogy „a települési önkormányzat maga határozza meg - a lakosság igényei alapján, anyagi lehetöségeitöl függöen -, hogy mely feladatokat, milyen mértékben és módon lát el"2, de az önkormányzati forráshiány egyre égetőbb problémaként jelentkezett, a települések közötti különbségeket jellemző olló tovább nyílt (Ferge, 2008). A lakóhelyből adódó sportbeli esélyegyenlőtlenség az utánpótláskorú

\footnotetext{
${ }^{2}$ Forrás: 1990. évi LXV. tv. II. Fejezet, 8. S (2)
} 
sportolókat különösképpen érinti. A hátrányos helyzetü településeken bizonyára sok tehetséges fiatal kallódik el, mert lakóhelyén nem adottak a feltételek arra, hogy egyáltalán megismerje azt a sportágat, amelyben később akár az élvonalba is kerülhetne (Földesiné, Gál és Dóczi, 2010).

A területi egyenlötlenségek feltérképezése Magyarországon eddig jellemzően települési és kistérségi szinten összegyüjtött adatok elemzésével zajlott (Velenczei, 2012). Több tanulmány is megfogalmazta, hogy a fejlödés és a lemaradás új térbeli határvonala Balassagyarmat és Békéscsaba vonalában, az ún. „BB” tengely mentén húzódik (Faluvégi, 2004). ${ }^{3}$ Mihály Ildikó a területi egyenlőtlenségeket oktatáspolitikai aspektusból vizsgálva (2000) arra a következtetésre jutott, hogy „bizonyos településtipusok - a nagyon elzárt települések, nagyvárosi óriási lakótelepek, nyomornegyedek - oktatási hátrányai nem földrajzi elhelyezkedésükböl, hanem szociális helyzetükböl fakadnak, de az ilyen környezet okozta esélyegyenlötlenség hatásmechanizmusa ugyancsak vitathatatlan." (Mihály, 2000, 90). Az idézett megállapítások ugyan egy oktatáspolitikai témájú tanulmány következtetései, mégis támpontként szolgálhatnak az utánpótlás sportban tapasztalható esélykülönbségek hátterének azonosításához.

A társadalmi rétegződésben elfoglalt hely a sportbeli esélyegyenlöség alakulásában is kitüntetett szerepet játszik. Olyannyira, hogy az egyének közötti társadalmi különbségek nem enyhülnek, hanem ellenkezőleg, felerősödnek a sportban (Földesiné, Gál és Dóczi, 2010). Utánpótláskorú fiatalok esetében a szülők társadalmi és gazdasági státusza, illetve sporttal kapcsolatos értékszemlélete döntő jelentőséggel bír a gyermekek sporthoz való viszonyának kialakulásában. Mivel a szükséges feltételeket csak „erős” családi háttér képes megteremteni, az élsportolói lét előszobájának tekinthető sportegyesületekbe elsősorban a gazdagabb, képzettebb szülők gyermekei tudnak bekerülni (Velenczei és mtsai, 2008).

A sport mobilizációs csatornaként, közvetlenül és közvetve hozzájárulhat a társadalmi hierarchiában való előrelépéshez. Kedvező irányú közvetlen mobilitásról akkor beszélhetünk, amikor a sport az egyén foglalkozásává, megélhetésének forrásává válik (Földesiné, Gál és Dóczi, 2010). A profeszszionális sport juttatásai lehetővé teszik a sportoló anyagi helyzetének javulását, a sikerekkel járó társadalmi elismertség pedig elősegíti kapcsolati tőkéjének gyarapodását (Róbert, 2001). Ez a fajta mobilitási lehetőség azonban csak keveseknek adatik meg, az utánpótlás-nevelési rendszerekbe történő bekapcsolódás pedig erős előfeltétele az élsportolói karriernek.

\section{A kutatás célja és hipotézisei}

Fentiekkel összhangban az empirikus kutatás elsődleges célja az utánpótláskorú sportolók - a labdarúgó akadémiai képzésben részesülő fiatalok társadalmi környezetének feltérképezése volt. Cél volt emellett azon esélykülönbségek feltárása is, amelyek már az élsportolóvá válás korai szakaszában éreztetik hatásukat. Vizsgáltuk, hogy mely társadalmi tényezők határozzák meg a gyermekek sportágba való bekapcsolódását és sportkarrierjük előrehaladását, továbbá azt is, hogy egy Magyarországon működő labdarúgó akadémia magas szintü sportszakmai képzése egyáltalán hozzáférhetö-e a kedvezötlenebb társadalmi hátterü fiatalok számára, és ha igen, a sport miként válhat a társadalmi mobilitás eszközévé.

\section{Kutatási kérdések:}

1. Beszélhetünk-e esélykülönbségekről az utánpótláskorú labdarúgók sportágba történő bekapcsolódását illetően, és ha igen, milyen dimenziókban tapasztalhatók egyenlötlenségek?

a. Milyen mértékben befolyásolja a fiatalok sportkarrierjének alakulását szüleik társadalmi helyzete?

b. Mennyiben határozza meg a gyermekek élsportolóvá válásának esélyeit lakóhelyük fejlettségi szintje?

c. Az utánpótlás-nevelési rendszerbe már bekerült fiatalnak származhat-e hátránya abból, ha szülei nem rendelkeznek jelentős kulturális tőkével a sport területén? Miben nyilvánulhat meg mindez?

2. A labdarúgás utánpótlás-nevelésében kulcsszerepet játszó akadémiák esetében milyen egyéb társadalmi funkciókról beszélhetünk azon felül, hogy a jövő élsportolóit képezik?

a. Miként segítheti elő egy labdarúgó akadémia a hátrányos helyzetủ fiatal sporttehetségek

\footnotetext{
${ }^{3}$ Ennek nyugati sávjában még javarészt dinamikusan fejlödö térségeket (pl.: Szeged kistérsége) és fejlödö térségeket (pl.: Szolnok kistérsége) találunk, a tengelytöl keletre viszont már - néhány dinamikusan fejlödö (pl.: Eger térsége) és fejlödö térségtöl (pl.: Debrecen, Nyiregyháza térsége) eltekintve - döntöen stagnáló és lemaradó térségek helyezkednek el. Míg a nyugati régiót a dél-dunántúli periféria aprófalvas térségeinek (pl. Belsö-Somogy) kivételével kedvezöbb gazdasági körülmények jellemzik, addig a keleti, észak-keleti települések súlyos hátrányokkal és lemaradásokkal küzdenek.
} 
társadalmi integrációját?

b. Egy utánpótlás-nevelő „műhely” hogyan képes csökkenteni a szociális háttérből következő esélyegyenlőtlenséget ifú sportolói körében?

\section{Az esélyegyenlöség dimenzióira vonatkozó hi- potézisek:}

$\mathrm{H}_{1}$ Feltételezhető, hogy az utánpótláskorú labdarúgók sportkarrierjének alakulását alapvetően meghatározza szüleik társadalmi helyzete, a kiemelt utánpótlásképző központokba túlnyomórészt a kedvezőbb anyagi és kulturális hátterủ családok gyermekei kerülhetnek be.

$\mathrm{H}_{2}$ Feltételezheto”, hogy a „regionális lejtő” a labdarúgás utánpótlás-nevelési rendszerében is érezteti hatását, vagyis a gazdaságilag fejlettebb térségek településeiről több fiatal érkezik a futballakadémiákra, mint a fejletlenebbekről.

$\mathrm{H}_{3}$ Feltételezheto, hogy a család sporthagyományai - elsősorban az édesapa, esetleg más közeli rokon személyes sportmúltja - döntő jelentőséggel bírnak az ifjú labdarúgók sportágválasztását illetően.

\section{A labdarúgó akadémiák társadalmi funkciói- ra vonatkozó hipotézisek:}

$\mathrm{H}_{4}$ Feltételezhető, hogy egy labdarúgó akadémián folyó utánpótlás-nevelés a képzés jellegéből adódóan túlmutat a kizárólagos sportszakmai felkészítésen. Ezáltal az intézménybe kerülő fiatalok olyan egyéb kompetenciák birtokába jutnak, amelyek segítik társadalmi integrációjukat, mobilitásukat.

$\mathrm{H}_{5}$ Feltételezhető, hogy a kedvezőtlenebb anyagi háttérrel rendelkező növendékek szociális alapú támogatásban részesülnek, így esetükben az akadémia hozzájárul az esélyegyenlőtlenség csökkentéséhez.

\section{Módszerek}

A primer adatgyüjtés Magyarország legrégebben működő és mind ez idáig a legtöbb első osztályú magyar labdarúgót kinevelő intézménye, a Sándor Károly Labdarúgó Akadémia agárdi székhelyén történt. Az itt nevelkedő utánpótláskorú labdarúgók megkérdezésére a survey módszert alkalmaztuk. Kérdéseink egyfelől a fiatalok sportba történő bekapcsolódásának körülményeire, a sportágválasztásukat befolyásoló tényezőkre, illetve a sportolói pályafutásukkal kapcsolatos várakozásaikra irányultak. Mindemellett azonosítani kívántuk azokat az egyenlőtlenségi dimenziókat - szülők társadalmi státusza, családi sporthagyományok megléte vagy hiánya, származási település fejlettségi szintje -, amelyeket sportolói karrierjük alakulása szempontjából meghatározó jelentőségűnek feltételeztünk. Az előzőleg összeállított kérdőivet 42 fö töltötte ki $(\mathrm{N}=42)$, ami a három akadémiai korosztály (U16os, U17-es és U19-es korosztály) 53 fös összlétszámát tekintve közel 80\%-os kitöltöttségi aránynak felel meg.

$\mathrm{Az}$ elsősorban statisztikai jellegű eredmények értelmezéséhez, a jelenségek hátterében húzódó összefüggések teljesebb megértéséhez a tanulmány első szerzője mélyinterjút készített a Sándor Károly Labdarúgó Akadémia igazgatójával. Az előzetes kérdésszerkesztéskor félig strukturált protokollt terveztünk, ami megadta az interjú vezérfonalát, ugyanakkor lehetőséget biztosított az interjúalanynak az általa fontosnak gondolt témák részletesebb kibontására is. További információforrást jelentettek az asszisztens edzőkkel és az intézmény kollégiumi nevelőtanárával folytatott, strukturálatlan informális beszélgetések.

A fent említett kutatási módszerekkel végzett kvantitativ és kvalitativ adatgyüjtés mellett a szekunder források tanulmányozására is kiemelt figyelmet fordítottunk. Dokumentumelemzés útján betekintést nyertünk a Sándor Károly Labdarúgó Akadémia sportfejlesztési programjába, majd az ott megfogalmazott célkitüzéseket összevetettük a szakszövetségi stratégiában ${ }^{4}$ foglaltakkal. Elsősorban annak kívántunk utánajárni, hogy a programalkotók által megfogalmazott irányelvek között találunk-e arra vonatkozó utalásokat, hogy egy labdarúgó akadémia az utánpótlásképzésben betöltött sportszakmai szerep mellett milyen egyéb társadalmi funkciókkal rendelkezik.

\section{Eredmények és megbeszélés}

Utánpótlás-nevelés, a labdarúgó akadémiákkal szemben támasztott követelmények

A Magyar Labdarúgó-szövetség tízéves időtartamra (2010-2020) vonatkozó sportágfejlesztési stratégiájának „félidei felülvizsgálata” szerint az

\footnotetext{
${ }^{4}$ A Magyar Labdarúgó-szövetség Elnöksége által 2011 augusztusában elfogadott „A magyar labdarúgás stratégiája-A megújulás évtizede 2010-2020” címü dokumentum utánpótlás-nevelésre vonatkozó fejlesztési koncepciója szolgált az összehasonlitás alapjául.
} 
utánpótlás-nevelés fejlesztését célzó intézkedések a tömegbázis növelését illetően sikeresnek bizonyultak: „A Bozsik-korosztályokban (U7-U15-ig) a versenyengedéllyel rendelkezö gyermekek száma 2010 és 2014 között mintegy 76\%-kal (37 ezer föröl 67 ezer fơre) noott. " A merítési lehetőség bővülésével a színvonalas utánpótlás-képzés egyik alapvető feltétele teljesült, a labdarúgó akadémiák egyes korosztályaiba (U16-U19-ig) ma már jóval nagyobb körből választhatók ki a tehetséges fiatalok, mint korábban.

$\mathrm{Az}$ Európai Labdarúgó-szövetség (UEFA) pontosan meghatározza, hogy milyen feltételeknek kell megfelelnie egy labdarúgó akadémiának. Ezen kritériumrendszer hazai adaptációjával a Magyar Labdarúgó-szövetség (MLSZ) olyan szabályozói környezetet teremtett, amelyben a Magyarországon működő futballakadémiák, illetve az akkreditációra jelentkező intézmények minősítési eljárásrendje is egységes irányelvek alapján zajlik. Az akadémiai cím elnyerésének feltételrendszere tartalmazza azokat a követelményeket, amelyek biztosítják, hogy licenchez csak a ténylegesen szakmai alapon működő utánpótlásképző központok juthassanak. ${ }^{6}$

A Sándor Károly Labdarúgó Akadémián tett látogatás alkalmával az intézményvezető betekintést engedett az Akadémia mindennapjaiba, a mélyinterjú keretében pedig részletesen ismertette az oktatással, lakhatással, ellátással, szakmai feltételekkel kapcsolatos tudnivalókat. Elmondása szerint a Sándor Károly Labdarúgó Akadémián nevelkedő játékosok, a helyi - agárdi székhelyü - Chernel István Általános Iskola és Gimnázium kihelyezett osztályaként, gimnáziumi oktatásban részesülnek. A fiataloknak így nem kell elhagyniuk az Akadémia területét, a tanórák a fóépület mellett található, hat tanteremből - köztük számítógépes teremből - álló iskolaépületben folynak. Az oktatást teljes mértékben sikerült összhangba hozni a futballképzéssel, az iskolai órarend is ennek megfelelően alakul. Heti háromszor (kedden, szerdán és csütörtökön) a gyerekek délelőtti edzésen vesznek részt, ezért ezeken a napokon a tanórák nagy része a délutáni idősávba kerül. Ugyanakkor az oktatás hatékonyságát növeli, hogy a diákok az egyes órákat kis létszámú (5-15 foss) csoportokban látogathatják. Az intézményben lakó nevelőtanár folyamatosan figyelemmel kíséri iskolai előmenetelüket, segíti felkészülésüket, egyéni beszélgetések keretében támogatja őket a mindennapokban, és rendszeresen szervez számukra közös programokat.

A szakmai igazgató a fiatalok ellátásával kapcsolatos részletekre is kitért: „Akadémiánkon teljes kényelmet biztositunk a gyerekeknek ahhoz, hogy az edzések, illetve a tanulás után ki tudják magukat pihenni. Intézményünk fóépületében 22 kétágyas szoba és 4 apartman található. A fiatalok szabadon rendezhetik be a szobájukat, és ök szabályozhatják a légkondicionálást és a fütést. A szobákban nincsen se televizió, se internet - ez kimondottan azt a célt szolgálja, hogy a pihenés helyszine legyen. A közösségi kikapcsolódás szintere a klubszoba. A megfelelö lakhatási körülmények biztositása mellett sportolóink étkeztetésére is kiemelt figyelmet forditunk. [...] Nagyon odafigyelünk arra, hogy a fiatalok a nap huszonnégy órájában tudjanak gyümölcsöt enni. Emellett a folyadékpótlásról kell gondoskodnunk, ásványvizet, szölöcukorral izesitett limonádét, illetve téli idöszakban teát biztositunk a gyerekeknek." (Tamási Zsolt, szakmai igazgató $^{7}$ - Sándor Károly Labdarúgó Akadémia)

\section{A sportkarrier kezdete, a sportágválasztás}

Egy kiemelt utánpótlásképző intézmény sportolóiról okkal feltételezhetjük, hogy elhivatottan, az élsportolóvá válás ambíciójával kezdtek el sportolni. Esetükben különösen érdekes a sportágválasztást befolyásoló tényezők azonosítása. Az ebben a témában folytatott korábbi kutatások (Géczi, Révész, Bognár, Vincze és Benczentleitner, 2005) eredményei arra mutatnak rá, hogy a különböző szocializációs közegek hatásait vizsgálva, a család, a szülők azok, akik leginkább befolyásolják gyermekük sportágválasztását. A Sándor Károly Labdarúgó Akadémián végzett személyes adatfelvétel során arra a kérdésre kerestem a választ, hogy az itt nevelkedő fiatalok körében is megfigyelhető-e ilyenfajta dominancia.

A kérdőívet kitöltők ( $\mathrm{N}=42)$ közül a válaszadók 69\%-a úgy nyilatkozott, hogy családja hatására választotta a labdarúgást (1. ábra). Közülük is markáns többségben $(72,4 \%)$ vannak azok a sportolók, akik édesapjuk hatására kezdtek el futballozni.

\footnotetext{
${ }^{5}$ Uo.: 43.0 .

${ }^{6}$ Lásd: A Magyar Labdarúgó-szövetség által 2012 januárjában készitett „Tájékoztató a labdarúgó akadémiai licencminösitési eljárásról” címü dokumentum (3-5.o.)

${ }^{7}$ Az interjúalany 2017 júniuság, 12 évig töltötte be ezt a posztot.
} 


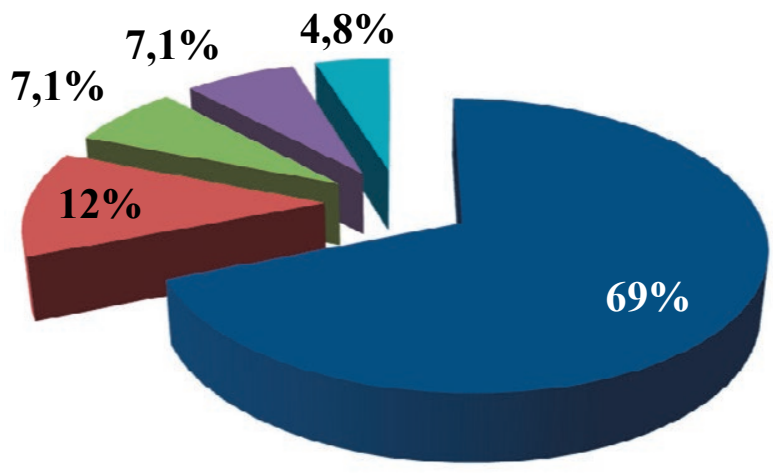

- Családom

- Saját elhatározásomból

- Barátom

- TV-ben látott futballsztár

- Testnevelöm

1. ábra: „Kinek a hatására választottad a labdarúgást?”

A fenti eredményekből egyértelműen kirajzolódik, hogy a kutatás alanyainak sportágválasztását leginkább családjuk befolyásolta. Ennek hátterében előzetesen a szülők sportszeretetét, a labdarúgással kapcsolatos pozitív attitüdjét, esetleg személyes sportági érintettségét feltételeztük. Hipotézisünk tesztelésére a vizsgálatba bevont sportolókat megkérdeztük családtagjaik sportmúltjáról.

A válaszadók 81\%-ának családjában található legalább egy olyan személy, aki jelentôs sportmúlttal rendelkezik, vagy jelenleg is üz valamilyen sportágat. Mivel korábbi kutatások eredményei arról tanúskodnak, hogy a szülők jellemzően olyan sportágat választanak gyermeküknek, amelyhez ők is kötődnek (Pápai és Szabó, 2003), célszerünek találtuk megvizsgálni, hogy azok közül a megkérdezettek közül, akik „sportos családból” érkeztek (a válaszadók $81 \%$-a), a családtagok sportági érintettsége mennyiben korlátozódik a labdarúgásra.

Az összesített adatok alapján az apák 55,9\%-a, a testvérek 14,7\%-a korábbi vagy jelenleg is aktív labdarúgó (2. ábra). A sportág családon belüli dominanciáját tovább erősíti, hogy a válaszadók $8,8 \%$-a nagyapját, míg 5,9\%-a nagybátyját is megjelölte, mint labdarúgó múlttal rendelkező családtagot. ${ }^{8}$

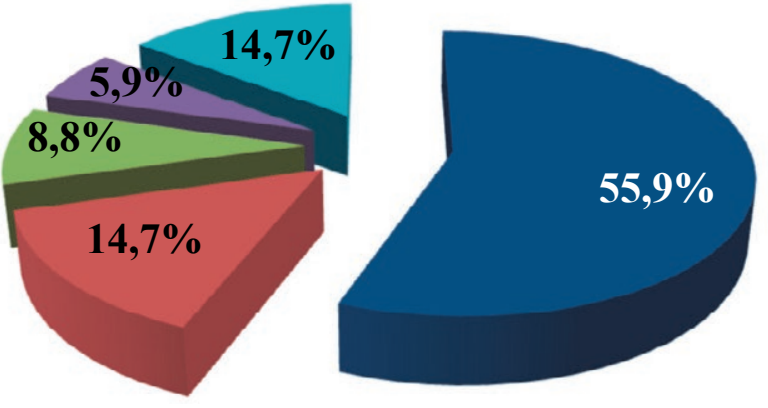

- Édesapám

- Testvérem

- Nagyapám

- Nagybátyám

Senki

2. ábra: „A családodban ki futballozik vagy futballozott korábban versenyszerűen?”

Az eredmények rávilágítanak, hogy a labdarúgásban eltöltött évekből adódó, szűken a labdarúgás területén értelmezhető kulturális („a családban sokan tudnak focizni”) és társadalmi tőkének („apukám, nagybátyám, stb. sok embert ismer a futballban") egyaránt szerepe van a futballtársadalom jelentős mértékű önreprodukciójában, melyben Pierre Bourdieu tőkeelméletének gyakorlati megvalósulását láthatjuk. Egyértelmủ szelekciós mechanizmusról azonban nem beszélhetünk, hiszen a válaszokból az is kiderült, hogy családi sporthagyományok hiányában sem lehetetlen bekerülni egy labdarúgó akadémiára.

Megállapítható továbbá, hogy a kutatás alanyai többségének körében a szülői modell - az édesapa személyes kötődése a labdarúgáshoz - nagymértékű ösztönző hatást gyakorolt a fiatalok sportágválasztására. Esetükben a sportszocializáció folyamata már kora gyermekkorban elkezdődött, hiszen a sportszerető apa, illetve más közeli rokon (pl. nagyapa)

\footnotetext{
${ }^{8}$ A sportági kötödés megállapitásakor kritériumként a versenyszerü sportolást határoztam meg, de a sportolói státuszok-amatör vagy hivatásos - között nem tettem különbséget.
} 
által olyan impulzusok érték őket, amelyek a futball iránti pozitív hozzáállásuk kialakulásához vezettek. Egyikük a következőképpen számolt be minderről:

„Mióta az eszemet tudom, a labdát rúgom. Nálunk a családban mindenki sportol, anyu kézilabdázik, apu focizik, most már csak megyei szinten, de korábban az NB II-ben is játszott. Nagyapám szintén futballozott, ö kapus volt annak idején. Mikor kicsik voltunk az öcsémmel, nagyon sokat focizott velünk. Mindig beállt a kapuba, mi pedig felváltva rúghattunk neki. Apu meccseire is ö vitt ki minket." (labdarúgó, Sándor Károly Labdarúgó Akadémia, U16os korosztály)

\section{A sportpályafutással kapcsolatos várakozások}

A felmérésben részt vevő utánpótláskorú labdarúgók sportágválasztását meghatározó tényezők azonosítása mellett azt is vizsgáltuk, hogy a fiatalok milyen célkitűzéseket fogalmaztak meg

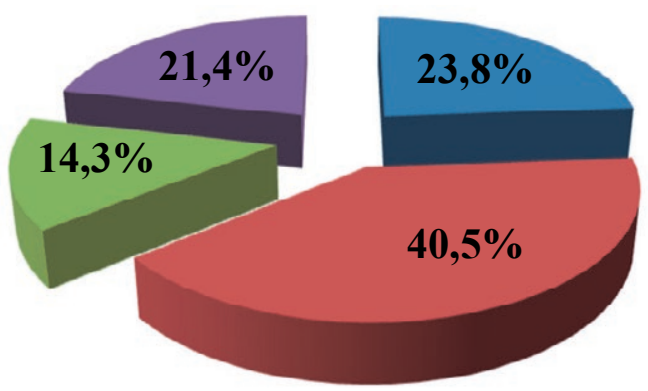

sportkarrierjük jövőbeni alakulását illetően. Mivel a Sándor Károly Labdarúgó Akadémia kiemelt utánpótlásképző központként működik, olyan válaszlehetőségeket határoztunk meg, amelyek hivatásos sportpályafutást feltételeznek. A megkérdezettek ambícióit jól jellemzi, hogy az első kategóriát („Bár nem leszek NB I-es játékos, de megélek a labdarúgásból.') senki sem jelölte meg. A fiatalok önmagukkal szemben támasztott minimális elvárása az NB I-ben való bemutatkozás. Ennek teljesülésével 23,8\%-uk lenne elégedett (3. ábra). Jóval többen vannak azonban, akik külföldi bajnokságban képzelik el sportolói karrierjük kibontakoztatását. A válaszadók 40,5\%-a a közepesen erős (pl. holland, belga, osztrák), 14,3\%-a pedig a legerősebb (pl. német, angol, spanyol) bajnokságok valamelyikébe szeretne igazolni. A válogatottban történő pályára lépést 21,4\%-uk tartja reális célkitűzésnek.

\section{- Sikerül bemutatkoznom az NB I-ben. \\ - Közepes erősségü külföldi bajnokságba is eljutok. \\ Külföldi topbajnokságba tudok igazolni. \\ - Pályára léphetek a válogatottban.}

3. ábra: „Sportkarriered jövőbeni alakulását tekintve, mivel lennél elégedett?”

A hosszú távú célkitűzések mellett arra is kíváncsiak voltunk, hogy sportkarrierjük jelenlegi szakaszában mit várnak el maguktól a megkérdezett fiatalok. Ennek felmérését ugyancsak ötfokozatú skála segítségével végeztük. Átlagolva a megjelölt értékeket, a sportszakmai fejlődés igénye nagyon markánsan (4,93-as átlag) kimutatható a válaszadók körében (4. ábra). Emellett az állandó játéklehetöséget (4,76-os átlag) és a csapattársak elismerésének kivívását (4,1-es átlag) tartják a legfontosabbnak. Ezt követi az edzői, majd a szülöi elvárásoknak való megfelelés (3,81-es, illetve 3,45-ös átlag).

A kutatás alanyainak sportpályafutásukra vonatkozó várakozásai, rövid és hosszú távú célkitűzései arra engednek következtetni, hogy valamennyien az élsportolóvá válás ambíciójával, maximális elhivatottsággal űzik sportágukat. A versenyzői életvitel, a bentlakásos rendszerü labdarúgó akadémiai képzés azonban jelentős erőfeszítéssel jár, és áldozatok sorát követeli a fiatalok részéről. A sportolói karrierre vonatkozó kérdések zárásaként ezért arra kértük őket, hogy jelöljék meg, milyen többlet nehézséggel szembesülnek a mindennapokban, és miről kell lemondaniuk céljaik elérése érdekében. ${ }^{9}$

A válaszok alapján megállapítható, hogy a megkérdezettek túlnyomó többsége $(85,7 \%)$ kevésnek érzi a szabadidejét (1. táblázat). 81\%-uk jelentős áldozatként értékeli, hogy nem tud a barátaival annyi időt eltölteni, amennyit szeretne. Ugyancsak sokan $(71,4 \%)$ említették, hogy nehezen élik meg a családjuktól való távollétet.

${ }^{9}$ A feleletválasztós kérdés meguálaszolásakor a sportolók több választ is megjelölhettek. 


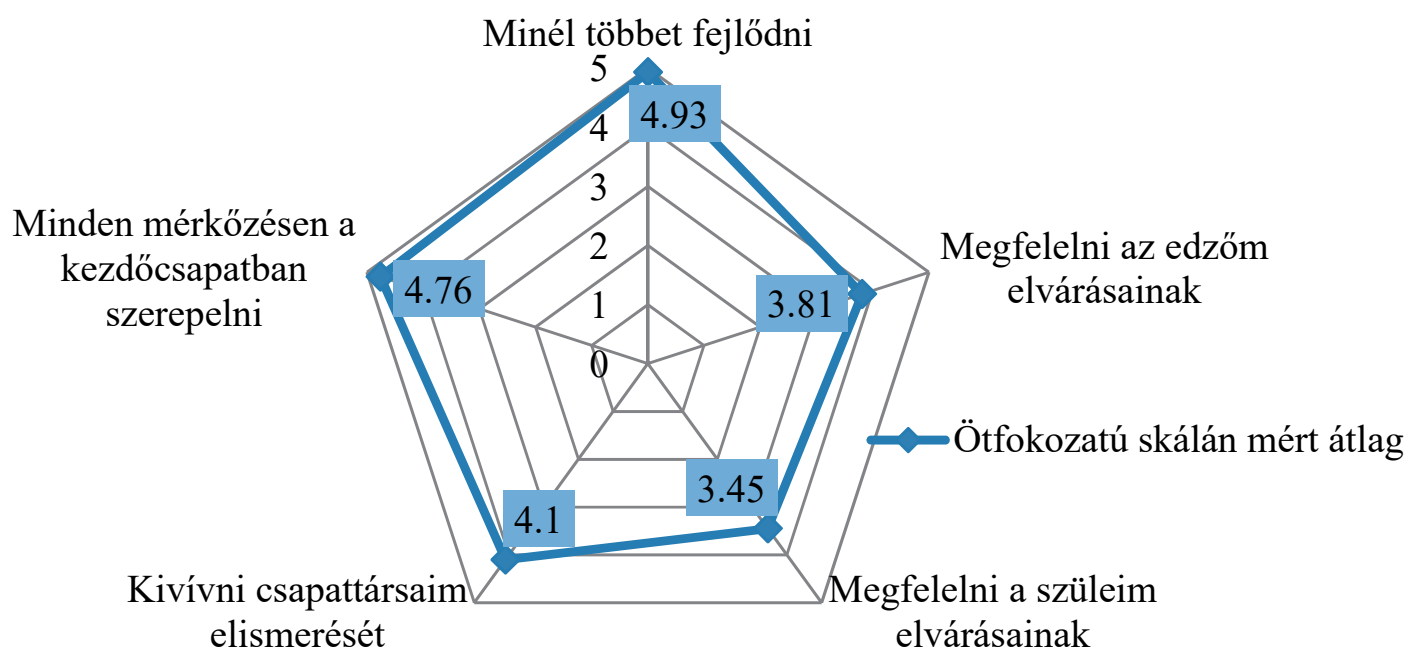

4. ábra: „A felsorolt célkitűzések mennyire motiválnak abban, hogy az edzéseken maximális erőbedobással dolgozz?"

Kiemelt utánpótlásképző központ sportolóiként az edzések és a tanulás összehangolása is kihívás elé állítja a fiatalokat. 45,2\%-uk véli úgy, hogy nem jut elég ideje a tanulásra. A versenyszerü sportolás további megpróbáltatásai között az étkezéssel kapcsolatos kötöttségek is felmerültek. A válaszadók harmada számára jár lemondással, hogy oda kell figyelnie a táplálkozásra.

1. táblázat: „Milyen áldozatokat kell hoznod annak érdekében, hogy sikeres sportolóvá válhass?”

\begin{tabular}{|c|c|c|}
\hline & Említések száma & Válaszadói \% \\
\hline Kevés a szabadidőm. & 36 & 85,7 \\
\hline $\begin{array}{c}\text { Nem tudok a barátaimmal annyi időt eltölteni, } \\
\text { amennyit szeretnék. }\end{array}$ & 34 & 81 \\
\hline Nem a családommal élek. & 30 & 71,4 \\
\hline Nem járhatok szórakozni, bulizni. & 29 & 69 \\
\hline Nem jut elég időm a tanulásra. & 19 & 45,2 \\
\hline $\begin{array}{c}\text { Oda kell figyelnem a táplálkozásra, } \\
\text { sokszor nem ehetem azt, amit megkívánok. }\end{array}$ & 14 & 33,3 \\
\hline
\end{tabular}

Származási település mint szelekciós tényezö „Az a lakóhely, ahová az egyén születik, ahol gyermek-és ifjúkorát tölti, iskolába jár, és ahol élete további szakaszaiban lakik, jelentösen befolyásolja sportolási esélyeit. [...] Magyarországon sincs a különbözö kategóriájú településeken felnövö gyerekeknek egyenlö esélye az élsportolói státus elérésére." (Földesiné, Gál és Dóczi, 2010, 61-62)

Az idézett állításokból kiindulva, a Sándor Károly Labdarúgó Akadémián végzett személyes adatfelvétel előtt azt feltételeztük, hogy ebbe a kiemelt utánpótlásképző központként működő intézménybe hátrányos helyzetű településekről jóval kisebb esélyük van bekerülni a fiataloknak, mint a gazdaságilag fejlettebb régiókból érkező társaiknak. Részben azért, mert az elmaradott térségek községeiben, kisvárosaiban megfelelő sportlétesítmények hiányában nem biztosítottak a sportolás feltételei, részben pedig, mert az itt élő gyerekek közelében nagyon kevés az olyan sportszakember, aki időben felismerhetné tehetségüket.

A vonatkozó hipotézis tesztelésére az előzőleg összeállított kérdőívben származási településük megjelölésére kértük a kitöltőket. Az alábbi térképen azok a városok (fôváros, megyei jogú városok, kisebb városok) és községek láthatók, ahonnan a Sándor Károly Labdarúgó Akadémiára érkeztek a fiatalok. 


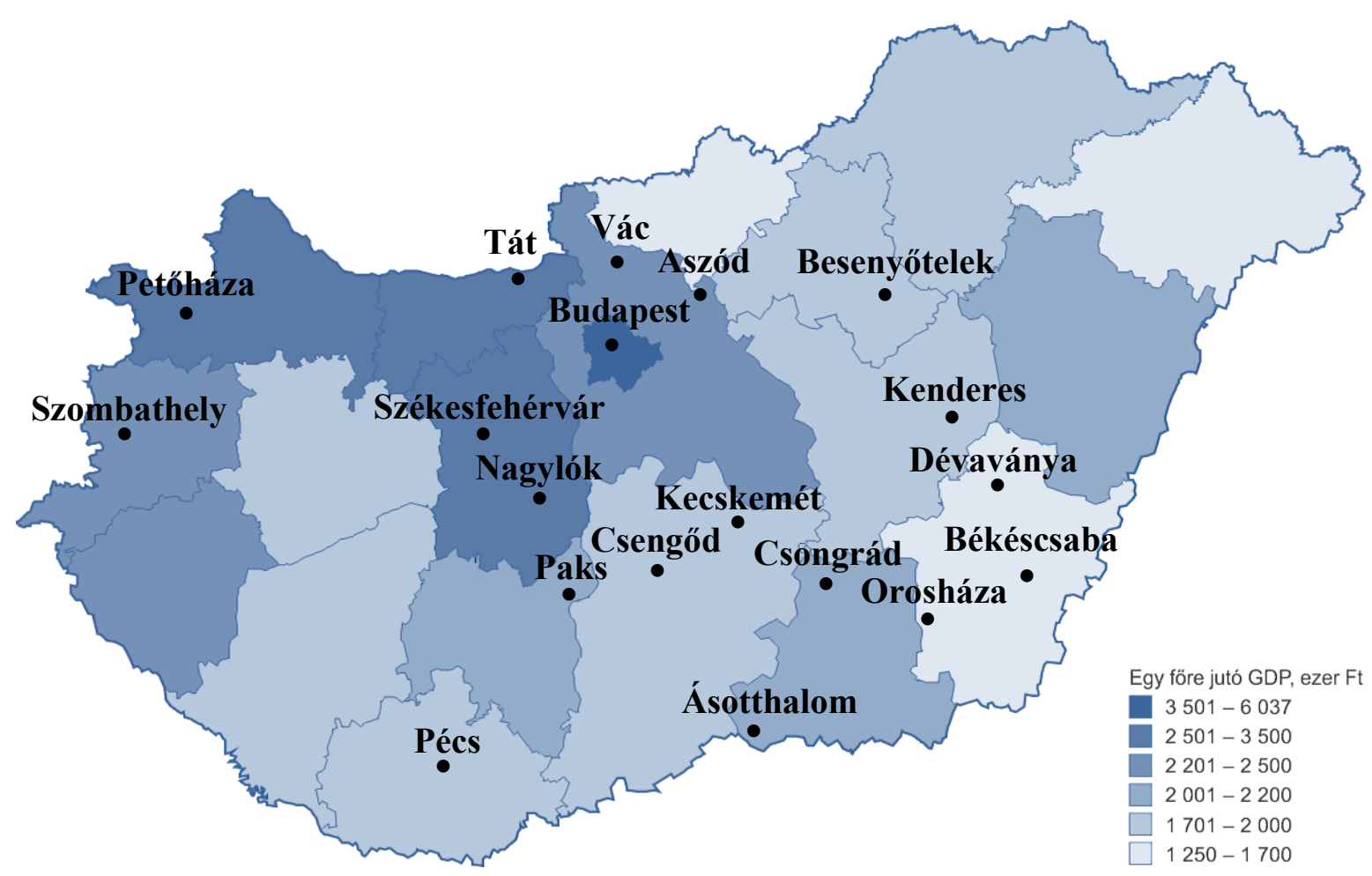

5. ábra: A Sándor Károly Labdarúgó Akadémián nevelkedő sportolók származási településének gazdasági fejlettségi szintje az adott megyében egy före jutó GDP függvényében

"A területi egységek gazdasági fejlettségi szintjét szemléltetö térkép forrása: $K S H$

A 42 megkérdezett sportoló közül Budapestről 19 fó, Pécsről 3 fö, Békéscsabáról, Kecskemétről és Székesfehérvárról 2-2 fö, míg a térképen jelölt többi településről 1-1 fó érkezett. Mindezen adatok ismeretében érdekesnek tartottam megvizsgálni, hogy a Sándor Károly Labdarúgó Akadémiára milyen arányban érkeztek a fiatalok a fejlettebb, és milyen arányban az elmaradottabb térségek településeiről. ${ }^{10}$

Ebből a szempontból sokatmondó információval szolgál az 5. ábra, amelyen láthatjuk, hogy Északkelet-Magyarország fent említett megyéiből a megkérdezettek közül egyetlen utánpótláskorú labdarúgó sem érkezett. Ugyanakkor az is jól leolvasható, hogy döntő többségük a Közép-magyarországi régióból - ezen belül 19 fö (a válaszadók 45,2\%-a) Budapestről -, illetve a Dél-alföldi régióból származik.

Végezetül összegyűjtöttük a sportolók származási településeire vonatkozó legfóbb adatokat (lakosságszám, jogállás...), amelyek alapján megállapítható, hogy a kutatás alanyainak $(\mathrm{N}=42)$ 69,1\%-a megyeszékhelyről, 11,9\%-a járási székhelyről, 7,1\%-a kisebb városból, 11,9\%-a pedig községből érkezett a Sándor Károly Labdarúgó Akadémiára. Utóbbi számadat azt bizonyítja, hogy egy-két ezer fős kisközségekből (pl. Petőházáról, Nagylókról, Csengődről, Besenyőtelekről) sem lehetetlen bekerülni az ország legrégebben működő és az első osztályú labdarúgók kinevelésében hazai szinten legeredményesebb utánpótlásképző intézményébe.

$\mathrm{Az}$ Akadémia szakmai igazgatója mindennek hátteréről a következőket mondta a mélyinterjú során:

"Játékosmegfigyelöi hálózattal rendelkezünk, valamint edzökollégáink jelen vannak a Bozsik Torna mérközésein. Az elmúlt években is kerültek hozzánk játékosok kis településekröl. A mai magyar futball

\footnotetext{
${ }^{10}$ Az egyes területi egységek gazdasági potenciálját az egy före jutó GDP alapján megvizsgálva kijelenthetö, hogy Magyarország legfejlettebb térségei a fövárost magában foglaló Közép-magyarországi régió mellett a Közép-dunántúli régió-ezen belül is elsösorban Fejér és Komárom-Esztergom megye - és a Nyugat-dunántúli régió (élen Györ-Moson-Sopron és Vas megyével). Ezzel szemben a válságjelekkel leginkább sújtott térség Északkelet-Magyarország, ahol Nógrád, Szabolcs-Szatmár-Bereg és Borsod-Abaúj-Zemplén megye gazdasági fejlettségi szintje a legalacsonyabb.
} 
rendszerben nagy az esélye a tehetséges gyerekeknek, hogy akadémiákra, élvonalbeli klubok utánpótlás mühelyeibe kerüljenek." (Tamási Zsolt, szakmai igazgató - Sándor Károly Labdarúgó Akadémia)

\section{Családi háttér mint egyenlötlenségi dimenzió}

Ahogy az „Elméleti háttér” című fejezetben már kitértünk rá, korábbi kutatási eredmények arról tanúskodnak, hogy az élsportolóvá válás lehetőségének terén komoly esélykülönbségek jellemzik a magyar utánpótlásképzést. Mivel a gyermekek verseny-sportoltatásának finanszírozása szempontjából meghatározó jelentőséggel bír családjuk társadalmi és gazdasági státusza, ennek feltérképezésére különös hangsúlyt fektettünk a Sándor Károly Labdarúgó Akadémián végzett felméréskor. Ennek megfelelően a kérdőív a szülők foglalkozására, illetve a család vagyoni helyzetére vonatkozó kérdést egyaránt tartalmazott. Ugyanakkor számolnunk kellett azzal a várható nehézséggel, hogy a kutatás alanyai - 15-18 éves fiatalok - esetleg nem rendelkeznek pontos információval szüleik jövedelméről. Ezért a kérdőívben arra kértük őket, hogy az átlaghoz képest értékeljék családjuk anyagi helyzetét. („Milyennek itéled családod anyagi helyzetét? (1) az átlagosnál sokkal rosszabb, (2) az átlagosnál rosszabb, (3) átlagos, (4) az átlagosnál jobb, (5) az átlagosnál sokkal jobb.') Emellett arra is rákérdeztünk, hogy megítélésük szerint sportkarrierjük költségeinek finanszírozása túlzott anyagi megterhelést jelent-e szüleik számára.

A válaszok összesítése után elmondható, hogy a megkérdezett sportolók 69\%-a az átlagosnál jobbnak, míg 11,9\%-a az átlagosnál sokkal jobbnak ítéli családja anyagi helyzetét (6. ábra). Átlagosnak 14,3\%-uk, az átlagosnál rosszabbnak pedig mindösszesen 2 fö (a válaszadók 4,8\%-a) értékeli vagyoni helyzetét. $\mathrm{Az}$ „átlagosnál sokkal rosszabb” válaszlehetőséget senki sem jelölte meg.

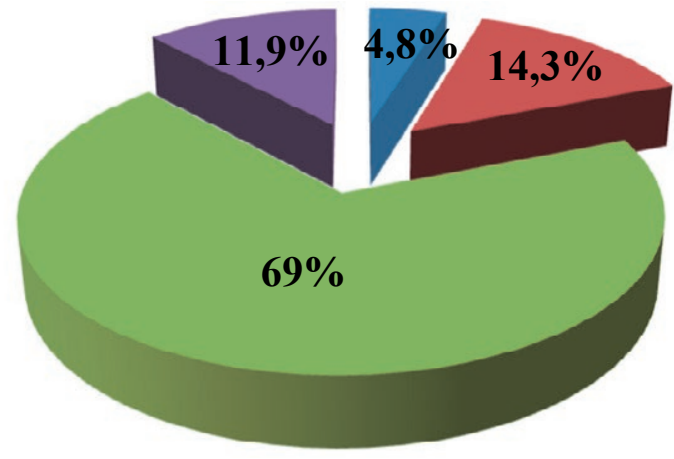

- Az átlagosnál rosszabb

- Átlagos

- Az átlagosnál jobb

- Az átlagosnál sokkal jobb

6. ábra: „Milyennek ítéled családod anyagi helyzetét?”

Családjuk társadalmi státuszának azonosítása után végezetül arra kérdeztünk rá, hogy a válaszadók érezték-e már valaha, hogy szüleikre túl nagy anyagi terhet ró az ő sportolásuk. A válaszadók kétharmada még soha nem tapasztalt ilyet, ellenben 26,2\%-uk családjában ritkán, míg 7,1\%-uknál gyakorta felmerül ez a kérdés (7. ábra).

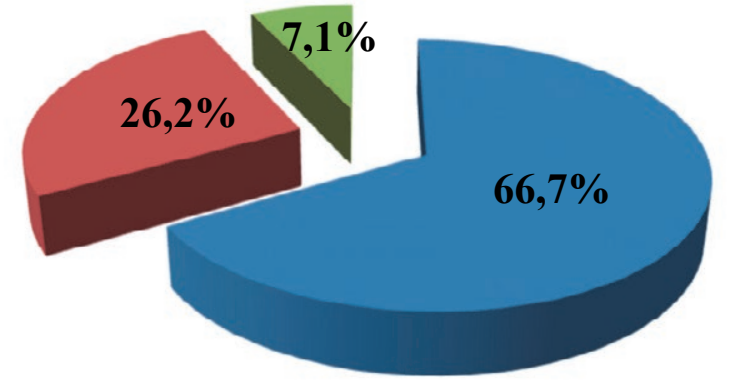

\section{Még soha nem éreztem. \\ - Ritkán már előfordult. \\ - Igen, ez a kérdés már sokszor felmerült.}

7. ábra: „Érezted-e már valaha, hogy családod számára túlzott anyagi megterhelést jelent annak finanszírozása, hogy sportolhass?” 
A nehézségek ellensúlyozása érdekében az Akadémia szakmai igazgatójának elmondása szerint hátrányos helyzetű sportolóikra kiemelt figyelmet fordítanak. A szociálisan nehéz körülmények között élőket ösztöndíjjal segítik.

\section{Összegzés, következtetések, javaslatok}

Kutatásunk során arra kerestük a választ, hogy az élsportolói lét előszobájának tekinthető elit utánpótlás-nevelő intézményekbe mekkora esélye van bekerülni egy hátrányos helyzetű fiatalnak, vagyis a sport mennyire nevezhető nyitott társadalmi alrendszernek.

Feltételezve az esélykülönbségek meglétét, az egyenlőtlenségek dimenzióiról hipotéziseket fogalmaztunk meg, melyek tesztelését a Sándor Károly Labdarúgó Akadémián folytatott primer adatgyűjtés eredményei alapján végeztük. A kérdőíves felmérés és a mélyinterjú során nyert információk elemzése után elmondható, hogy valamennyi feltételezésünk beigazolódott.

Noha a társasági adókedvezmény sporttámogatási rendszerének (TAO-program) 2011-es bevezetése óta a korábbihoz képest jelentős többletforráshoz jut az utánpótlássport, a kutatás eredményei arról tanúskodnak, hogy a fiatalok sportbeli esélyegyenlötlensége továbbra is létezö probléma. A dotáció következtében mérséklödött ugyan a szülök anyagi megterhelése - gyermekük sportolásának finanszírozása már nem jelent akkora kiadást számukra -, de a jelentös forrástöbblet nem eredményezte automatikusan a hátrányosabb helyzetben lévö fiatalok tömeges megjelenését a rendszerben. A kiemelt utánpótlásképző központokba még mindig nagyobb arányban érkeznek jó anyagi és életkörülményekkel jellemezhető családokból a gyerekek.

Ugyancsak beigazolódott azon feltételezésünk, miszerint az utánpótláskorú fiatalok lakóhelyének fejlettségi szintje is meghatározó jelentöséggel bir a sportba történő bekapcsolódásuk esélyeit illetően. A gazdasági tekintetben elmaradott térségekböl jóval nehezebb bekerülni egy kiemelt utánpótlásképző központba. Sokatmondó információ, hogy a kutatás résztvevői közül senki sem származik Északkelet-Magyarország hátrányos helyzetű térségeiből. Ugyanakkor a "települési lejto" (fóváros, megyeszékhely, város, község, falu) mentén már nem mutathatók ki ilyen arányú esélykülönbségek, hiszen a megkérdezettek közel negyede kisebb városból vagy községből érkezett az Akadémiára.
$\mathrm{Az}$ utánpótláskorú fiatalok sportágválasztását befolyásoló tényezőkre vonatkozó hipotézisünk szintén igazolást nyert. A válaszadók több mint kétharmada családja hatására választotta a labdarúgást, ami azt bizonyítja, hogy a gyermekek sportszocializációjának szempontjából a szük társadalmi környezet szerepe meghatározó. Az esettanulmány eredményei alapján az is kijelenthetö, hogy a család sporthagyományai, a sportkulturális tőke megléte vagy hiánya éppúgy sportbeli esélyegyenlőtlenségi dimenzió, mint a vagyoni helyzet vagy a származási település. Különösen akkor indulnak esélytöbblettel a fiatalok, ha közeli hozzátartozóik közül valaki rendelkezik kifejezetten a labdarúgás területén értelmezhető kulturális és szociális tőkével.

A labdarúgó akadémiák társadalmi funkcióiról előzetesen megfogalmazott feltételezéseink ugyancsak beigazolódtak. Megismerve a Sándor Károly Labdarúgó Akadémián folyó utánpótlás-nevelés szisztematikusan felépített rendszerét, megállapítható, hogy a sportszakemberek, illetve az intézmény pedagógusai a képzés és a nevelés kettős elvei mentén foglalkoznak a gyerekekkel. Ahogyan egyikük fogalmazott, nemcsak az a cél, hogy profi futballisták, hanem az is, hogy értelmes felnöttek váljanak a fiatalokból.

A labdarúgó utánpótlás-nevelésre vonatkozó javaslataink fókuszában egy olyan tehetségkutató rendszer kiépitésének elképzelése áll, amely kifejezetten azoknak a hátrányos helyzetü fiataloknak a megtalálását célozná, akik szeretnének a futballal komolyan foglalkozni, de családjuk rossz anyagi körülményei, illetve lakóhelyük elmaradottsága ezt nem teszik lehetővé. Az ilyen kedvezőtlen háttérrel rendelkező fiatalok tehetségmentésében kulcsszerep hárul a szakképzett testnevelökre. Ök ugyanis közvetlen kapcsolatban állnak a gyerekekkel. Ahhoz azonban, hogy a sporttehetség jegyeit mutató fiatalokat megfelelő sportegyesületekhez tudják irányítani, arra volna szükség, hogy az utánpótlásképzés vidéki bázisai újjáépüljenek. Ezek a „műhelyek” aztán ösztöndijrendszer elinditásával a szociálisan nehéz körülmények között élő gyerekeket is beemelhetnék a labdarúgó utánpótlás-nevelés rendszerébe.

A fenti elképzelés megvalósíthatóságának esélyeit növelik az utóbbi években országszerte, több száz településen lezajlott pályaépítések és sporttelep-felújítások, de az infrastrukturális háttér megteremtése önmagában nem elegendö. A sportegyesületek szakmai megerösitése és fejlödésre ösztönzö támogatása 
legalább annyira fontos, mint a létesítményfejlesztés. Annak érdekében, hogy a kisebb utánpótlás-nevelo" centrumokban is korszerü képzésben részesüljenek a fiatalok, megfelelo" létszámú és tudású sportszakemberre van szükség. Olyan edzőkre, akik birtokában vannak mindazon kompetenciáknak - szakmai felkészültség, pedagógiai képességek, alázat, szociális érzékenység - amelyek alkalmassá teszik őket hivatásuk professzionális gyakorlására. Mindemellett, mivel a hátrányos helyzetủ fiatalokat célzó programokban a sporttartalom mellett szociális kompetenciák fejlesztésére is szükség van, fóként az előkészítési és az értékelési fázisokban szociális szakemberek bevonása is célszerü lenne.

Köszönetnyilvánítás: A tanulmány szerzői ezúton is köszönetüket fejezik ki Tamási Zsoltnak, a Sándor Károly Labdarúgó Akadémia szakmai igazgatójának és tanítványainak a kutatás önzetlen támogatásáért.

\section{Felhasznált irodalom}

1. 1990. évi LXV. törvény a helyi önkormányzatokról URL: http://mkogy.jogtar. hu/?page=show\&docid=99000065.TV (letöltés ideje: 2016. március 31.)

2. 1996. évi LXXXI. törvény a társasági adóról és az osztalékadóról URL: http://net.jogtar.hu/jr/gen/hjegy_doc. cgi?docid=99600081.TV (letöltés ideje: 2016. március 31.)

3. 1997. évi XXXI. törvény a gyermekek védelméről és a gyámügyi igazgatásról URL: http://net.jogtar.hu/jr/gen/hjegy_doc. cgi?docid=99700031.TV (letöltés ideje: 2016. március 31.)

4. 2003. évi CXXV. törvény az egyenlő bánásmódról és az esélyegyenlőség előmozdításáról URL: http://net.jogtar.hu/jr/gen/hjegy_doc. cgi?docid=A0300125.TV (letöltés ideje: 2016. március 31.)

5. Balogh L., Kádár A. K., Majtényi B. és Pap A. L. (2010): Antidiszkriminációs és esélyegyenlőségi alapismeretek. Budapest: L'Harmattan.

6. Bodnár I. (2015): Egyenlőség - egyenlőtlenség - esélyegyenlőség a sportban. In: Laczkó T. és Rétsági E. (szerk.): A sport társadalmi aspektusai. Pécs: Pécsi Tudományegyetem Egészségtudományi Kar, 109-137.

7. Borraccino, A., Lemma, P., Iannotti, R.J.,
Zambon, A., Dalmasso, P., Lazzeri, G., Giacchi, M., Cavallo, F. (2009) Socioeconomic effects on meeting physical activity guidelines: comparisons among 32 countries. Medicine and Science in Sports and Exercise 41(4), 749-56.

8. Bourdieu, P. (2000) Gazdasági tőke, kulturális tőke, társadalmi tőke. In: Felkai G., Némedi D. és Somlai P. (szerk.): Szociológiai irányzatok a 20. században. Budapest: Új Mandátum. 431-445.

9. Charter of Fundamental Rights of the European Union $=$ Az Európai Unió alapjogi chartája (2000). Official Journal of the European Communities, 18. 12. URL: http://www. europarl.europa.eu/charter/pdf/text_en.pdf (letöltés ideje: 2016. március 31.)

10. Coakley, J. (2011) Youth Sports: What Counts as „Positive Development?” Journal of Sport and Social Issues 35(3) 306-324

11. Coakley, J. (2015) Sport in Society: Issues and Controversies. St. Louis, CV Mosby.

12. Dóczi T. (2014): Sport és hátrányos helyzet. In Farkas J. (szerk.) A fizikai aktivitás és a sport magyarországi dimenzióinak feltárása. Budapest: MSTT-MST, 104-128.

13. Egressy J. (2005): Társadalmi esélyegyenlőtlenségek a versenysportban. Az úszás példája. PhD disszertáció, Budapest: Semmelweis Egyetem.

14. Fábri I. (2002): A sport, mint a fiatal korosztályok életmódjának meghatározó eleme. In: Szabó A., Bauer B. és Laki L. (szerk.): Ifjúság2000 Tanulmányok I. Budapest: Nemzeti Ifjúságkutató Intézet, 166-179.

15. Faluvégi A. (2004): A társadalmi-gazdasági jellemzők területi átalakulása és várható hatásai az átmenet időszakában. Budapest: MTA-KTK.

16. Ferge Zs. (2008): Miért szokatlanul nagyok a magyarországi egyenlőtlenségek? Esély, 2, 3-14.

17. Földesiné Sz. Gy., Gál A. és Dóczi T. (2010): Sportszociológia. Budapest: SE-TSK.

18. Gál A. (2008): A lakosság egészségtudatossága és szabadidő-sportolási szokásai. In: Földesiné Sz. Gy., Gál A. és Dóczi T. (szerk.): Társadalmi Riport a Sportról. Budapest: MSTTÖTM, 9-39. 
19. Géczi G., Révész, L., Bognár, J., Vincze, G. és Benczentleitner, O. (2005): Talent and talent development in sports: the issue of five sports. Kalokagathia, 3, 113-123.

20. Kelly, L. (2011) 'Social inclusion' through sports-based interventions? Critical Social Policy 31(1), 126-150.

21. Magyar Labdarúgó-szövetség (2011, szerk.): A magyar labdarúgás stratégiája - A megújulás évtizede 2010-2020. URL: http:// katalizatorhalozat.hu/sites/default/files/mlsz_ strategia1.pdf (letöltés ideje: 2016. március 31.)

22. Magyar Labdarúgó-szövetség (2012, szerk.): Tájékoztató a labdarúgó akadémiai licencminősítési eljárásról. Kézirat.

23. Mihály I. (2000): Esélyegyenlőség - az első híján van-e második esély? Új Pedagógiai Szemle, 3, 89-98.

24. Nyerges M. és Laki L. (2004): A fiatalok sportolási szokásainak néhány társadalmi öszszefüggése. Magyar Spottudományi Szemle, 2-3, 5-15.

25. Pápai J. és Szabó T. (2003): Tornászgyermekek sportágválasztását befolyásoló tényezők. Kalokagathia, 1, 18-32.

26. Perényi Sz. (2010): The relation between sport participation and the value preferences of Hungarian youth. Sport in Society, 13(6), 984-1000.
27. Róbert P. (2001): Társadalmi mobilitás: a tények és vélemények tükrében. Andorka R. Társadalomtud. Társ., Századvég, Budapest.

28. Stalsberg, R., Pedersen, A. V. (2010) Effects of socioeconomic status on the physical activity in adolescents: a systematic review of the evidence. Scandinavian Journal of Medicine \& Science in Sports 20(3) 368-383.

29. United Nations (1948): Universal Declaration of Human Rights / Az emberi jogok egyetemes nyilatkozata. URL: http://www.un.org/ en/universal-declaration-human-rights/index.html (letöltés ideje: 2016. március 31.)

30. Velenczei A. (2012): Társadalmi esélyegyenlőtlenség az utánpótláskorú sportolók körében az államilag finanszírozott programokban résztvevők esetében. $\mathrm{PhD}$ disszertáció, Budapest: Semmelweis Egyetem.

31. Velenczei A., Kovács Á., Szabó T. és Szabó A. (2008): Társadalmi változások a magyarországi sportutánpótlás-nevelésben egy sportegyesület tükrében. Magyar Sporttudományi Szemle, 4, 25-30. 